\title{
Measuring Repurchase Intention on Fashion Online Shopping
}

\author{
Ivanna Syifa Johan ${ }^{1 *}$, Ratih Indriyani ${ }^{1}$, and Zane Vincēviča-Gaile ${ }^{2}$ \\ ${ }^{1}$ Department of Management, Faculty of Business and Economics, Petra Christian University, \\ Jl. Siwalankerto 121-131, Surabaya 60236, Indonesia \\ ${ }^{2}$ Department of Environmental Science, University of Latvia, Riga LV-1050, Latvia
}

\begin{abstract}
The internet has become one of many ways for consumers to shop. With the rapid development of internet connection, online shopping has become increasingly popular around the world. All forms of conveniences available through online businesses have lured consumers to switch from offline shopping to online slowly. This research emphasizes the influence of e-service convenience on customer satisfaction, perceived service value, and repurchase intention on fashion online shopping websites in Surabaya. The sample is taken from 115 Surabaya respondents. The sampling technique uses a non-random sampling technique. The analytical method used is the partial least square (PLS). The results show that e-service convenience has a significant impact on customer satisfaction, customer satisfaction has a significant impact on repurchase intention, e-service convenience has a significant impact on repurchase intention, and perceived value has a significant impact on repurchase intention. The results also show the importance of customer satisfaction which influences repurchase intention. Online fashion business owners must promote their websites so that more consumers know about the existence of online shopping fashion websites. Business owners must also increase the convenience and comfort of consumers in shopping online.
\end{abstract}

Keywords: Customer satisfaction, e-service convenience, fast-shopping, perceived value, repurchase intention

\section{Introduction}

The internet is one of the many ways used by consumers today to shop. Consumers visit various websites that offer various products to sell, choose products, order products, make credit card payments, and finally, sellers send products physically [1]. A similar statement is made by [2] stating that the internet is often used for online shopping. Online shopping refers to the shopping behavior of consumers in online stores or websites that are used for online purchasing purposes. With the rapid development of the internet, online shopping is increasing and becoming a popular way to shop around the world. The percentage of consumers involved in online shopping and income also shows a significant increase) [3].

\footnotetext{
*Corresponding author: ranytaa@petra.ac.id
} 
Specifically, this research will discuss online shopping activities in the online shopping fashion category. Bai et al., explain that the use of e-commerce websites for fashion shopping activities is increasingly popular [4]. This is due to one of them because, in addition to offering B2C models, fashion shopping websites also offer $\mathrm{C} 2 \mathrm{C}$ concepts that make the choice of fashion products offered increasingly varied both in terms of product types and prices.

In Indonesia, the most promising main segment for an online business is the working generation. In a report prepared by the Asian Development Bank Institute (ADBI), Hassyati explains that the main target segments of online shopping activities are people who have worked both men and women with middle and upper economic groups [5] This is because the working generation will tend to be more exposed to the internet all the time. The increasing demand for online shopping, especially in early adulthood, is accompanied by increased competition among emerging virtual companies and many traditional retailers who have used the internet as a convenience-oriented channel. Therefore, business people must clearly understand what constitutes service convenience in e-commerce business. Understanding of the convenience of business consumers can be used to increase customer satisfaction so that repurchases occur to consumers.

Convenience is the key to understanding shopping behavior, where consumers attach a significant increase. Convenience is defined as a reduction in the amount of time and energy consumers need to obtain and use a product or service relative to the time and energy required to make repeat purchases at the online store.

Convenience obtained by consumers when shopping online will have an impact on several things. Pham et al. explain that one of the effects of convenience experienced by consumers is the value perceived by consumers [3]. Bai et al., explain that perceived value illustrates the ratio between the quality and perceived benefits of the product or service relative to the sacrifice perceived by consumers by making payments [4]. In addition to influencing perceived value, convenience also impacts on customer satisfaction. Mehmood and Najmi explain that the convenience of shopping online can affect consumer satisfaction, meaning that consumers who feel comfortable in online shopping activities at the same time will experience an increase in perceived satisfaction from online shopping activities [6].

Satisfied consumers will tend to revisit websites that are used to shop online. Chen et al. explain that customer satisfaction will improve repurchase behavior [8]. Repurchase intention refers to the psychological condition or commitment to a product or service that arises after using it and gives rise to the intention to consume more. In the context of online shopping, repurchase intention is a subjective probability that someone will continue to buy products from vendors or online stores in the future. Besides being influenced by satisfaction factors that are felt by consumers, repurchase intention can also be influenced by the perceived value experienced by consumers, as stated by [3] in his research. Muhammad suggests that several factors can influence customer intent repurchase on shopping websites where one of them is perceived value [9].

This study aims to analyze the effect of e-service convenience on customer satisfaction and e-service convenience on perceived value. This study also wants to examine the effect of customer satisfaction on repurchase intention and the effect of e-service convenience on repurchase intention.

\section{Literature review}

\subsection{Perceived value}

Perceived value is the customer's overall assessment of the benefits of the product or service, service quality, price, the emotional and social value of a product or service based 
on perceptions about what is received and given by the customer. This value is the key to customer loyalty, which affects the customer's desire to make a purchase. In general, value is the consumer's perception of the subjective value of some activity or object by considering all the benefits and costs of that consumption. When consumers buy products from a company, they not only buy products but also receive a set of values from the company. The brand of a company is several values that represent the company itself [10]. Pham et al. explain that perceived value can be measured using the indicator value obtained from the website, the comparison between the time and energy expended when shopping online [3]. Perceived value is also seen from the convenience when doing online shopping.

\subsection{E-Service convenience}

Jiang et al. state that convenience is the key to understanding shopping behavior, where consumers attach a significant increase [11]. Convenience is defined more briefly as a reduction in the amount of time and energy consumers needed to obtain, use, and dispose of a product or service relative to the time and energy required by other offerings in a product or service, and suggest two-dimensional construction organized in the acquisition, use and disposal phase. Meixian in his research, reveals three indicators that can be used to measure e-service convenience, including the reduced time, energy used when shopping online, and less energy spent [12]. The three indicators are a measurement of customer comfort in online shopping.

\subsection{Customer satisfaction}

Customer satisfaction is the company's final goal in providing quality services to customers. Satisfaction is defined as the feeling of a satisfied or disappointed customer over the result of comparing the perceived performance of the product (or result) about customer expectations. If performance fails to meet expectations, the customer will be dissatisfied. If the performance is in line with expectations, the customer will be satisfied. If performance exceeds expectations, the customer will be very satisfied or happy [11]. Huang et al., measure customer satisfaction through indicators of experience in using products, satisfaction with decisions, desire to buy products, and the belief of the product quality [13].

\subsection{Repurchase intention}

Repurchase intention is a major concern for companies that want to gain a competitive advantage, and are considered by academics and practitioners. It is also intended to repeat the purchase of certain products or services from time to time. In the online context, it is defined as the reuse of online channels to buy from specialized retailers [14]. In other studies, repurchase intention refers to the psychological commitment to a product or service that arises after using it, which results in ideas for consumption again. Repurchase intention is very important for profit and is an object that is discussed in company evaluations. In addition, repurchase intention also refers to the extent to which consumers are willing to buy a product or service again and is a simple, objective, and observable purchase behavior expected [13]. Anggraeni et al., explain that to determine repurchase intention, it is measured using indicators: want to buy back products in the future, are reluctant to switch to other brands [18]. Repurchase intention is also measured by reducing information search before repurchasing. 


\section{The relationships among concepts and hypothesis}

\subsection{The e-service convenience to customer satisfaction}

Mehmood and Namji in their research, found that service convenience has a significant positive impact on customer satisfaction [6]. This is because one of the conveniences obtained from online shopping activities is in terms of shipping goods quickly and efficiently. The main difference between online and offline shopping is product acceptance, although by shopping offline, the product can be taken home immediately, with fast delivery of the current system, online shopping also offers relatively fast delivery features, and this is what makes consumers feel comfortable with shopping online. Duarte, Silva and Ferreira also get similar results where a service convenience has a significant positive effect on customer satisfaction [17]. In this research, it is explained that the convenience that arises from shopping online appears due to various reasons such as convenience in gaining access to products, convenience in transactions, convenience felt before and after online shopping activities. All forms of comfort provided in shopping online will cause satisfaction for consumers. Based on these researches, the hypothesis is constructed as:

H1: e-service convenience has a significant positive impact on customer satisfaction.

\subsection{Customer satisfaction to repurchase intention}

Muhammad finds that customer satisfaction will have a significant positive effect on repurchase intention [8]. One of the reasons for online shopping satisfaction is caused by responsive customer service from the seller. Satisfaction from the experience gained during online shopping will create an intention for consumers to return to making purchases or shopping activities online. The result is also supported by the results obtained in a study [7] This study explains that satisfied consumers will automatically intend to make a repurchase intention. Satisfaction in this study is measured with the feelings experienced by consumers during shopping activities and also with the comparison between the expectations that consumers have of the product against the reality received. If consumer expectations for products and services are met, consumers will tend to feel satisfied and intend to buy again. Based on these researches, the hypothesis is constructed as:

$\mathrm{H} 2$ : customer satisfaction has a significant positive impact on repurchase intention.

\subsection{The e-service convenience to repurchase intention}

Pham et al., examine the relationship between service convenience and perceived value and repurchase intention [3]. From this study, it is found that service convenience has a significant positive effect on repurchase intention. Service convenience in this study is measured based on the speed of consumers to find the desired product, the ease of using online shopping websites and the appearance of products that make it easy to choose. Consumers who shop online will more quickly find the items they want to buy. Besides that in general, e-commerce websites already have features that are user-friendly making it easier for consumers to use the website and learn about product appearance. This makes consumers have a pleasant shopping experience and raises the intention of consumers to buy back products through websites that have been used. Based on the description from the previous research above, the hypothesis constructed for this study is:

H3: e-service convenience has a positive significant impact on repurchase intention. 


\subsection{The e-service convenience to perceived value}

Pham et al., found that service convenience has a significant positive effect on perceived value [3]. Consumers who shop online will more quickly find the items they want to buy; besides that in general, e-commerce websites already have features that are user-friendly making it easier for consumers to use the website and learn about product appearance. This affects how consumers view the perceived value of shopping online. Consumers will view that shopping online has a quality value because of the convenience and comfort experienced in shopping. Based on these researches, the hypothesis is constructed as:

H4: e-service convenience has a significant positive impact on perceived value.

\subsection{The perceived value to repurchase intention}

Pham et al., also find that perceived value has a significant positive effect on repurchase intention [3]. Consumers who already understand that the value obtained by online shopping activities is better will tend to choose to buy back online either through a website that has been used or through a new website. Characteristics of consumers who intend to repurchase products online are intentions that arise to continue to shop online, the intention to recommend websites that have been visited in online shopping to others, and the intention to make websites that have been visited as the first choice for shopping activities online in the future. Based on the description from the previous research above, the hypothesis constructed for this study is:

H5: perceived value has a positive significant impact on repurchase intention

\section{Research method}

This type of research is quantitative with a causality approach. The causality approach is a research approach to see the effect between one variable with other variables [18]. The population in this study is the early adulthood people living in Surabaya who fullfil some criteria. The sample is part of the number and characteristics possessed by the population [18]. In this study, using non-random sampling techniques, namely by judgmental sampling. This research has 18 parameters so that the number of samples to be obtained is $6 \times 18=108$ respondents, then decided into 115 respondents. The sample criteria in this study are as follows: aged $18 \mathrm{yr}$ to $40 \mathrm{yr}$ (early adulthood) and have used the website to do online shopping in the last 3 mo. The data are analyzed with smart PLS software.

\section{Data analysis}

\subsection{The outer model evaluation}

\subsubsection{Convergent validity}

Convergent validity can be seen based on the score of the loading factor. The loading score value is shown on the line in the path diagram that connects the indicator with the variable. The following results of the first test of convergent validity test are presented in tabular form: Convergent validity test has a condition that the indicator must have a loading value greater than 0.5. While indicators that have values below 0.5 will be deleted. Based on the results of data processing, there is one item that value is below 0.5. Then the item is considered invalid and is deleted. After re-processed again and analyzed using an outer model evaluation, all items and indicators have a loading value greater than 0.5 . So, the 
researchers conclude that the results of the second test have met the requirements of the convergent validity test.

\subsubsection{Discriminant validity}

Discriminant validity is assessed based on cross-loading measurements with the constructs. If the correlation value between indicators and constructs is greater than the correlation value between other indicators and other constructs, then it shows that the latent construct predicts the size of the block better than the size of other blocks. If these conditions are met, then the indicator meets the requirements that exist in discriminant validity. From the results of cross loading, it appears that all indicators have met the discriminant validity requirements because the value of the indicator variable has the greatest value of the others, so this meets the discriminant validity requirements.

\subsubsection{Composite reliability}

Based on the results of the conducted test, all variables have composite reliability and Cronbach's alpha values greater than 0.6 , so it can be said that each of the research variables has met the requirements of composite reliability and Cronbach's alpha. It can also be said that the variables above are reliable.

\subsection{The inner model evaluation}

The result of R square is 0.476 or $47.6 \%$. This shows that the diversity of the variables of e-service convenience, perceived value, and customer satisfaction can affect repurchase intention by $47.6 \%$

The hypothesis testing in PLS is done by t-test analysis. The T-test is done by comparing the value of t-count (t-statistic) and the value of t-table at the level of error (margin of error) of $\alpha=5 \%$ or 1.96 . The hypothesis can be accepted if the value of $t$-count is greater than the value of t-table, or in other words if the t-count $>1.96$. With the smartPLS 3.0, the t-test is performed by doing the bootstrapping process. The result of the bootstrapping can be observed in Fig. 1 .

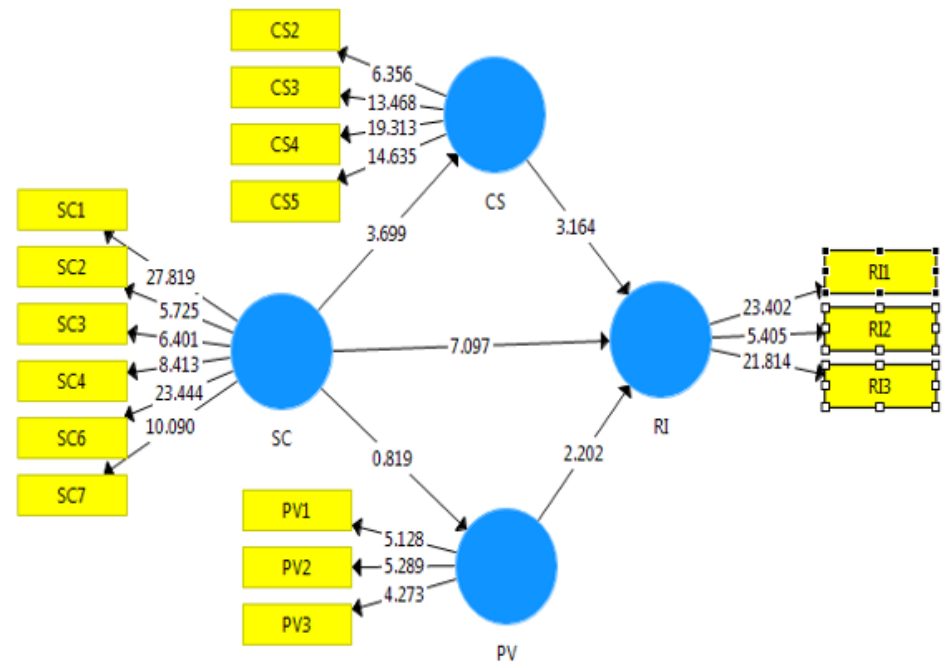

Fig. 1. The Bootstrapping result 


\subsection{Hypothesis test}

Table 1. Path coefficient, standart error, and t-statistic

\begin{tabular}{|l|l|c|c|c|c|}
\hline \multicolumn{2}{|c|}{ Hypothesis } & $\begin{array}{c}\text { Original } \\
\text { Sample (O) }\end{array}$ & $\begin{array}{c}\text { T Statistics } \\
(\mid \text { O/STERR } \mid)\end{array}$ & P Values & Remark \\
\hline H1 & $\begin{array}{l}\text { Customer Satisfaction -> Repurchase } \\
\text { Intention }\end{array}$ & 0.232 & 3.164 & 0.002 & Accepted \\
\hline H2 & Perceived Value -> Repurchase Intention & 0.176 & 2.202 & 0.028 & Accepted \\
\hline H3 & $\begin{array}{l}\text { E-Service Convenience -> Cutomer } \\
\text { Satisfaction }\end{array}$ & 0.334 & 3.699 & 0.000 & Accepted \\
\hline H4 & $\begin{array}{l}\text { E-Service Convenience -> Perceived } \\
\text { Value }\end{array}$ & 0.105 & 0.819 & 0.413 & Rejected \\
\hline H5 & $\begin{array}{l}\text { E-service Convenience -> Repurchase } \\
\text { Intention }\end{array}$ & 0.531 & 7.097 & 0.000 & Accepted \\
\hline
\end{tabular}

The results of testing the hypothesis are as follows:

Variable customer satisfaction has a significant impact on repurchase intention, because the T-Statistic value is 3.164 which means it is greater than 1.96. Thus, the hypothesis that reads "Customer satisfaction affects repurchase intention on fashion online shopping websites" can be accepted.

The perceived value variable has a significant impact on repurchase intention because the T-Statistic value is 2.202 which means it is greater than 1.96 . Thus, the hypothesis that reads "Perceived value influences repurchase intention on fashion online shopping websites" can be accepted.

The e-service convenience variable has a significant effect on customer satisfaction because the T-Statistics value is 3.699 which means it is greater than 1.96. Thus, the hypothesis that reads "E-service convenience affects customer satisfaction on fashion online shopping websites" can be accepted.

The e-service convenience variable has no significant effect on perceived value because the T-Statistic value is 0.819 , which means it is smaller than 1.96 . Thus, the hypothesis that reads "E-service convenience affects the perceived value of fashion online shopping websites" is rejected.

The e-service convenience variable has a significant effect on repurchase intention because the T-statistic value is 7.097 which means it is greater than 1.96. Thus, the hypothesis which reads "E-service convenience has an effect on repurchase intention on fashion online shopping websites" can be accepted.

\section{Discussion}

\subsection{The impact of e-service convenience to customer satisfaction}

The results obtained in this research indicate that the e-service convenience variable has a significant effect on customer satisfaction. This is due to the convenience that arises from shopping online goes up due to various reasons such as convenience in gaining access to products, convenience in transactions, convenience felt before and after online shopping. All forms of comfort provided in shopping online will cause satisfaction for consumers [6] Online shopping fashion websites can make it easier for consumers, especially consumers at the age of early adulthood. Consumers at this age want to get the product or item they want easily and quickly. With e-service convenience helping to attract consumers with the convenience of the services presented above, one of them is that consumers only need a little time to find the desired item. 


\subsection{The impact of customer satisfaction to repurchase intention}

The results obtained in this study indicate that the variable customer satisfaction has a significant effect on repurchase intention. Chen et al. in their study state that satisfied consumers will automatically intend to make a repurchase intention [7]. Satisfaction in this study is measured based on the feelings experienced by consumers during shopping activities and also based on the comparison between the expectations that consumers have of the product against the reality received. If consumer expectations for products and services are met, consumers will tend to feel satisfied and intend to buyback. The results show that consumers, especially at the age of early adulthood (18 yr to $40 \mathrm{yr}$ ), feel that the decision to buy goods on fashion online shopping websites is the right decision so that it can trigger consumers' desire to make repeat purchases on online fashion shopping websites.

\subsection{The impact of e-service convenience to repurchase intention}

In this research, it is found that the e-service convenience variable has a significant influence on repurchase intention. E-service convenience in this study is measured based on the speed of consumers to find the desired product, the ease of using online shopping websites, and the appearance of products that make it easy to choose. Consumers who shop online will more quickly find the items they want to buy, and besides that, in general, ecommerce websites already have features that are user-friendly making it easier for consumers to use the website and learn about product appearance [3]

\subsection{The impact of e-service convenience to the perceived value}

The results obtained in this research indicate that the e-service convenience variable does not significantly influence the perceived value. Consumers who shop online will more quickly find the items they want to buy [19]. Besides that in general, e-commerce websites already have features that are user-friendly making it easier for consumers to use the website and learn about product appearance. Consumers will view that shopping online has a quality value because of the convenience and comfort experienced in shopping [3].

\subsection{The impact of perceived value to repurchase intention}

The results obtained in this study indicate that perceived value has a significant effect on repurchase intention. Pham et al. in their research state that consumers who have understood that the value obtained by online shopping activities is better will tend to choose to buy back online either through a website that has been used or through a new website [3]. Characteristics of consumers who intend to repurchase products online are intentions that arise to continue to shop online, the intention to recommend websites that have been visited in online shopping to others, and the intention to make websites that have been visited as the first choice for shopping activities online in the future.

\section{Conclusion}

E-service convenience has a positive and significant impact on customer satisfaction. Customer Satisfaction has a positive and significant impact on repurchase intention. Similarly, perceived value has a positive and significant impact on repurchase intention. In this study, it is found that e-service convenience has a positive and significant impact on repurchase intention. Consumer comfort and customer satisfaction in shopping online play 
an important role in repurchasing consumers. Online shopping fashion websites should further improve their services, facilities and products so that consumers who have already bought their products are more satisfied and, in the future, want to buy products that they have bought on the online shopping fashion website. Online shopping fashion websites should further improve services such as giving more choices and options for goods so that consumers can find the desired item more easily.

\section{References}

1. S.M. Umair, H.M. Bilal, M. Akhtar, M, M.S. Bhatti, Journal of Sociological Research, 5,1:248-272(2014). http://www.macrothink.org/journal/index.php/jsr/article/view/6565

2. U. Cheema, M. Rizwan, R. Jalal, F. Durrani, N. Sohail, Journal of Empirical Research, 3,2:131-141(2016). http://www.aessweb.com/pdf-files/131-141.pdf

3. Q.T. Pham, X.P. Tran, S. Misra, R. Maskeliunas, R. Damaseviciu, Sustainability, 10:156(2018). https://www.mdpi.com/2071-1050/10/1/156

4. Y. Bai, C. Li, J. Niu, American Journal of Industrial and Business Management, 6:915-916(2016).

http://www.scirp.org/journal/PaperInformation.aspx?paperID=70256

5. A.N. Hasyyati, Demographic and Socioeconomic Characteristics of E-Commerce Users in Indonesia. ADBI Working Paper 776. Tokyo: Asian Development Bank Institute (2017). p. 1-25. https://www.adb.org/sites/default/files/publication/363381/adbi-wp776.pdf

6. S.M. Mehmood, A. Najmi, International Journal of Electronic Customer Relationship Management, 11,1:23-43(2017).

https://pdfs.semanticscholar.org/8fa5/6eb4e83c5a7b09099c1083f01d65e6dd4818.pdf

7. C.M Chen, H.T Lee, S.H. Chen, T.H. Huang, International Journal of Tourism Research, 13:5416-432(2014). https://onlinelibrary.wiley.com/doi/abs/10.1002/jtr.810

8. F. Muhammad, AU-GSB e-Journal, 6,1:44-51(2013). http://www.assumptionjournal.au.edu/index.php/AU-GSB/article/view/462

9. I. Bernato, Patricia, Journal for Business and Entrepeneur, 1,10:36-34(2017). http://journal.uta45jakarta.ac.id/index.php/JBE/article/view/720

10. L. Jiang, Z. Yang, M. Jun, Jurnal of Service Management, 24,2:191-214(2012). https://www.emeraldinsight.com/doi/abs/10.1108/09564231311323962

11. M.T Tjoanoto, Y.S Kunto, Jurnal Manajemen Pemasaran Petra 1,1:1-9(2013). [in Bahasa Indonesia]. http://publication.petra.ac.id/index.php/manajemenpemasaran/article/view/126

12. L. Meixian, The Anthropologist, 21(1-2):8-17(2015). http://krepublishers.com/02Journals/T-Anth/Anth-21-0-000-15-Web/Anth-21-1-2-000-15-Abst-PDF/T-ANTH21-1,2-008-15-1467-Li-Meixian/T-ANTH-21-1,2-008-15-1467-Li-Meixian-Tx[2].pdf

13. C.C. Huang, S.W. Yen, C.Y. Liu, T.P. Chang. International Journal of Organization Innovation, 6,3:106-120(2014). http://ijoionline.org/attachments/article/38/FINAL_ISSUE_VOL_6_NUM_3 JANUARY 201 4.pdf\#page $=106$

14. Y. Liu, B. Pu, Z. Guan, Q. Yang, Asia Pacific Journal of Tourism Research, 10:122(2015).

https://www.researchgate.net/profile/Bo_Pu/publication/282869860

15. C.L.W. Lekhawipat, Industrial Management \& Data System, 144,4:597-611(2014). https://www.emeraldinsight.com/doi/abs/10.1108/IMDS-10-2013-0432 
16. M. Anggraeni, N. Farida, L. Sari, Jurnal of Social and Political of Science, 2015:19(2015). [in Bahasa Indonesia].

https://ejournal3.undip.ac.id/index.php/jiab/article/download/9289/9019

17. P. Duarte, S.C. Silva, M.B. Ferreira. Journal of Retailing and Consumer Service, 44:161-169(2018).

https://www.sciencedirect.com/science/article/pii/S096969891830225X

18. Sugiyono. Metode Penelitian Kuantitatif Kualitataif dan Kombinasi (Mixed Methods). [Research Methods on Qualitative, Quantitative, and Mixed Methods]. Bandung:

Alfabeta (2016). [in Bahasa Indonesia]. https://books.google.co.id/books?id=0xmCnQAACAAJ

19. L. Jiang, N. Jiang, S. Liu. Procedia Environmental Science, 11:406-410 (2011). https://www.sciencedirect.com/science/article/pii/S1878029611008887 